\title{
Paleolimnological Evidence of Terrestrial and Lacustrine Environmental Change in Response to European Settlement of the Red River Valley, Manitoba and North Dakota Étude paléolimnologique des changements environnementaux terrestres et lacustres à la suite du peuplement européen dans la vallée de la rivière Rouge, au Manitoba et dans le Dakota du Nord
}

\author{
Barbara E. Medioli, Aruna Dixit, John P. Smol, Thane W. Anderson et Susan M. \\ Burbidge
}

Volume 59, numéro 2-3, 2005

URI : https://id.erudit.org/iderudit/014756ar

DOI : https://doi.org/10.7202/014756ar

Aller au sommaire du numéro

Éditeur(s)

Les Presses de l'Université de Montréal

ISSN

0705-7199 (imprimé)

1492-143X (numérique)

Découvrir la revue

Citer cet article

Medioli, B. E., Dixit, A., Smol, J. P., Anderson, T. W. \& Burbidge, S. M. (2005). Paleolimnological Evidence of Terrestrial and Lacustrine Environmental Change in Response to European Settlement of the Red River Valley, Manitoba and North Dakota. Géographie physique et Quaternaire, 59(2-3), 263-275. https://doi.org/10.7202/014756ar
Résumé de l'article

Cette étude établit une corrélation entre les changements limnologiques et terrestres dans la plaine d'inondation de trois lacs et le peuplement de la vallée de la rivière Rouge au Manitoba et dans le Dakota du Nord. Divers assemblages polliniques, de diatomées et de thécamoébiens mettent en évidence de façon indirecte des changements écologiques entre les périodes pré- et post-peuplement aux alentours des lacs Horseshoe, Louise et Salt. Dans la période antérieure au peuplement (Zone I), soit avant 1812, la domination de la signature pollinique des graminées et du chêne indique un écosystème forestier riverain composé de graminées de haute taille et de chênes. Quant aux assemblages de diatomées et de thécamoébiens, ils permettent de penser à des conditions limnologiques d'oligo à mésotrophiques et des eaux plus saumâtres à cette période qu’actuellement dans le lac Horseshoe. La période post-peuplement (Zone II) correspond à des changements terrestres et limnologiques spécifiques. Le déclin marqué du chêne à la base de cette zone correspond en effet à la déforestation des rives de cette région, telle qu'attestée dans les documents, tandis que les taxons Salsola, Brassica, Rumex et Ambrosia correspondent à l'instauration de pratiques agricoles européennes et la culture des céréales. Les assemblages de diatomées et de thécamoébiens indiquent aussi une eutrophisation progressive de la plaine inondable de même que l'augmentation de la salinité du lac Salt, ce dernier étant le plus salé des trois lacs. Il accueille des foraminifères d'eaux saumâtres du genre Trochammina macrescens cf. polystoma. L'accroissement de l'érosion et du ruissellement dans le bassin-versant a quadruplé la sédimentation entre les périodes pré- et post-peuplement. 


\section{PALEOLIMNOLOGICAL EVIDENCE OF TERRESTRIAL AND LACUSTRINE ENVIRONMENTAL CHANGE IN RESPONSE TO EUROPEAN SETTLEMENT OF THE RED RIVER VALLEY, MANITOBA AND NORTH DAKOTA*}

Barbara E. MEDIOLI**, Aruna DIXIT, John P. SMOL, Thane W. ANDERSON and Susan M. BURBIDGE; first and second authors: Geological Survey of Canada, Natural Resources Canada, 601 Booth Street, Ottawa, Ontario K1A 0E8, Canada; second and third authors: PEARL, Department of Biology, Queens University, Kingston, Ontario K7L 3N6, Canada; fourth author: 25 Dexter Drive, Ottawa, Ontario K2H 5W3, Canada; fifth author: 311 Golf Links Road, Ancaster, Ontario L9G 2N6, Canada.

ABSTRACT Limnological and terrestrial changes in three floodplain lakes are correlated with settlement of the Red River valley in Manitoba and North Dakota. Distinctive pollen, diatom and thecamoebian assemblages provide proxy evidence of the ecological changes from pre- to post-settlement periods in Horseshoe Lake, Lake Louise and Salt Lake. In the pre-settlement period (Zone I), prior to 1812 , grass and Quercus pollen dominate and are indicative of a tall grass prairie-oak riparian forest ecosystem. Diatom and thecamoebian assemblages suggest oligo- to mesotrophic limnological conditions, and more brackish water than presently occurs in Horseshoe Lake. The onset of the post-settlement period (Zone II) corresponds to distinctive terrestrial and limnological changes. A sharp decline in Quercus at the base of this zone correlates with documented regional riparian deforestation, whereas the increase in the weed taxa Salsola, Brassica, Rumex and Ambrosia is associated with the introduction of European agricultural practices and cereal grasses. Diatom and thecamoebian assemblages indicate progressive floodplain lake eutrophication, as well as increased salinity in Salt Lake. Salt Lake is the most brackish lake and supports the brackish-water foraminifera Trochammina macrescens cf. polystoma. Increased erosion and run off in the watershed has caused a more than twofold increase in lake basin sedimentation between the pre-settlement and post-settlement periods.
RÉSUME Etude paléolimnologique des changements environnementaux terrestres et lacustres à la suite du peuplement européen dans la vallée de la rivière Rouge, au Manitoba et dans le Dakota du Nord. Cette étude établit une corrélation entre les changements limnologiques et terrestres dans la plaine d'inondation de trois lacs et le peuplement de la vallée de la rivière Rouge au Manitoba et dans le Dakota du Nord. Divers assemblages polliniques, de diatomées et de thécamoébiens mettent en évidence de façon indirecte des changements écologiques entre les périodes pré- et post-peuplement aux alentours des lacs Horseshoe, Louise et Salt. Dans la période antérieure au peuplement (Zone I), soit avant 1812, la domination de la signature pollinique des graminées et du chêne indique un écosystème forestier riverain composé de graminées de haute taille et de chênes. Quant aux assemblages de diatomées et de thécamoébiens, ils permettent de penser à des conditions limnologiques d'oligo à mésotrophiques et des eaux plus saumâtres à cette période qu'actuellement dans le lac Horseshoe. La période post-peuplement (Zone II) correspond à des changements terrestres et limnologiques spécifiques. Le déclin marqué du chêne à la base de cette zone correspond en effet à la déforestation des rives de cette région, telle qu'attestée dans les documents, tandis que les taxons Salsola, Brassica, Rumex et Ambrosia correspondent à l'instauration de pratiques agricoles européennes et la culture des céréales. Les assemblages de diatomées et de thécamoébiens indiquent aussi une eutrophisation progressive de la plaine inondable de même que l'augmentation de la salinité du lac Salt, ce dernier étant le plus salé des trois lacs. Il accueille des foraminifères d'eaux saumâtres du genre Trochammina macrescens cf. polystoma. L'accroissement de l'érosion et du ruissellement dans le bassin-versant a quadruplé la sédimentation entre les périodes pré- et post-peuplement.

Manuscrit reçu le 15 juillet 2005 ; manuscrit révisé accepté le 15 février 2006 (publié le $1^{\text {er }}$ trimestre 2007)

* Geological Survey of Canada contribution number 2005444

${ }^{* *}$ E-mail address: bmedioli@nrcan.gc.ca 


\section{INTRODUCTION}

Lake basins are natural repositories for evidence of past paleoenvironmental change. Sediments and biotic remains accumulating through time record changes within the lacustrine environment and in the surrounding watershed. Micropaleontological, sedimentological, geochemical and chronological studies of lake sediments assist to characterize and date anthropogenic, climatic and trophic changes. Limnological studies in the eastern Canadian and American prairies have broadened the understanding of the deglacial history of the Northern Great Plains (Last, 1982, 1983, 1999; Last et al., 1994; Teller and Last, 1981, 1983) and on Holocene climatic changes (Henderson and Last, 1999; Tackman et al., 1999; Todd et al., 1999a, 1999b), particularly with respect to aridity (Anderson et al., 1993; Bradbury and Dean, 1993; Bradbury and Dietrich-Rurup, 1993; Brugam, 1993; Lemmen and Vance, 1999; Nuhfer et al., 1999; Whitlock et al., 1999). Only a handful of studies, however, have documented recent changes during the last few centuries, dealing with eutrophication (Burbidge and Schröder-Adams, 1998; Torigai et al., 2000), shoreline submergence (Nielsen, 1999), vegetation change from tall grass prairie to agricultural landscape (Brooks and Grenier, 2001; Jacobson and Engstrom, 1989) and increased sedimentation (Brooks and Grenier, 2001; De Boer, 1994; Shapley et al., 2005).

The Red River basin is the largest watershed in the eastern prairies. The river occupies a shallow $(15 \mathrm{~m})$, narrow (2 $500 \mathrm{~m}$ ) valley that is incised into the glacial Lake Agassiz clay plain (Brooks and Nielsen, 2000). The river flows north making it prone to spring floods caused by snowmelt, ice-jamming or both. In 1997 the third largest historical flood since 1648 (St. George and Nielsen, 2003) inundated large areas of the Red River valley in southern Manitoba, western Minnesota and eastern North Dakota. As a result of this flood, studies were initiated to improve the understanding of the frequency and magnitude of extreme Red River floods (St. George and Nielsen, 2002, 2003) and the geomorphic and geological factors influencing the flood hazard (Brooks, 2003b; Brooks et al., 2004). Part of this research focused on Red River floodplain lakes to assess their potential for containing a paleoflood record (see Medioli, 2003) and to better understand regional paleoenvironmental change (Brooks and Grenier, 2001; Medioli and Brooks, 2003a).

This paper documents recent paleoenvironmental changes recorded in the lacustrine deposits of three lakes within the 1997 Red River flood zone. Changes in the vegetation of the Red River watershed are interpreted from pollen spectra while diatom and thecamoebian assemblages record changes in the limnology of the lakes arising from the arrival of European settlers and the introduction of agriculture, as presented below. This study documents the timing and events associated with regional European settlement and their impacts on lacustrine eutrophication, including the effect of large-scale agricultural practices on changes in sedimentation rates and salinity. It further contributes an improved perspective of recent environmental change on floodplain lakes in the eastern prairies, particularly with respect to the limnological and environmental impacts of agriculture and settlement.

\section{STUDY LAKES}

The Red River is a low-energy, suspended-load meandering river. It has a gentle gradient and a slow rate of lateral channel migration which results in a paucity of floodplain oxbow lakes (Brooks, 2002, 2003a, 2003b; Brooks and Medioli, 2003). Only two perennial lakes, Horseshoe Lake and Lake Louise, occur between the Canada-U.S.A. border and the city of Winnipeg (Brooks, 2003), and are part of this study. The third perennial lake in this study is Salt Lake, North Dakota. All three lakes occur within the flood zone of the Red River (Medioli, 2003) and are inundated by river waters during moderate to extreme flood peaks. The threshold discharge of inundation for Lake Louise is equivalent to approximately $1500 \mathrm{~m}^{3} / \mathrm{s}$ at Emerson, which has been surpassed seven times during the $20^{\text {th }}$ century.

The Red River watershed lies on the eastern edge of the tall grass prairie. Most of the watershed is used for agriculture and the modern agrarian ecosystem is dominated by wheat, canola, alfalfa and barley. In the vicinity of the study lakes is an abundance of cropland dedicated to flax, oats, sunflowers, soy and hemp. A narrow riparian forest corridor surrounds the modern day river which, in order of distance away from the river, consists primarily of cottonwood (Populus), willow (Salix), basswood (Tilia), ash (Fraxinus), Manitoba maple (Acer negundo), American elm (UImus americana) and bur oak (Quercus macrocarpa) (St. George and Nielsen, 2001).

Horseshoe Lake is an oxbow lake located $1 \mathrm{~km}$ east of the Red River, near the town of Morris, Manitoba (Fig. 1). The lake is $150 \mathrm{~m}$ wide, $1250 \mathrm{~m}$ long and up to $2 \mathrm{~m}$ deep (Fig. 2A). This groundwater-fed lake is brackish (Betcher et al., 1995) and hypereutrophic (Medioli, 2003), as defined by Wetzel (2001). Due to high macrophyte productivity throughout the late spring and summer months, the modern sediment-water interface is anoxic (Medioli, 2003). The timing of oxbow cutoff at Horseshoe Lake is dated at 1990 cal BP or shortly thereafter (Brooks and Medioli, 2003).

Lake Louise is a channel scar lake, up to $2.4 \mathrm{~m}$ deep, located $2 \mathrm{~km}$ from the Red River near the town of Emerson, Manitoba (Fig. 1). This elongate lake is $175 \mathrm{~m}$ wide, $2050 \mathrm{~m}$ long and slightly sinuous (Fig. 2B). Lake Louise is a former channel of the Red River, abandoned by a channel avulsion of unknown timing (Brooks and Grenier, 2001) but presumed to be early Holocene (Brooks and Medioli, 2003). The presentday lake waters are hypereutrophic and the sediment-water interface is anoxic (Medioli, 2003). Macrophyte production is high in late spring and throughout the summer months.

Salt Lake is a small, oblong lake located $10 \mathrm{~km}$ west of the Red River, near the town of Grafton, North Dakota (Fig. 1). This lake is not a channel scar of the Red River but rather a low lying area on the prairie surface. Salt Lake is shallow (maximum depth at time of coring $0.7 \mathrm{~m}$ ), $500 \mathrm{~m}$ wide and $1600 \mathrm{~m}$ long (Fig. 2C). Lake water conductivity is elevated $(6.80 \mathrm{mS} / \mathrm{cm}$; Medioli, 2003) and groundwater fed. During winter coring, icefree patches were observed on the lake, with water bubbling to the surface. Salt Lake is hypereutrophic but has well-oxygenated water and sediment columns, in contrast to Horseshoe Lake and Lake Louise (Medioli, 2003). 


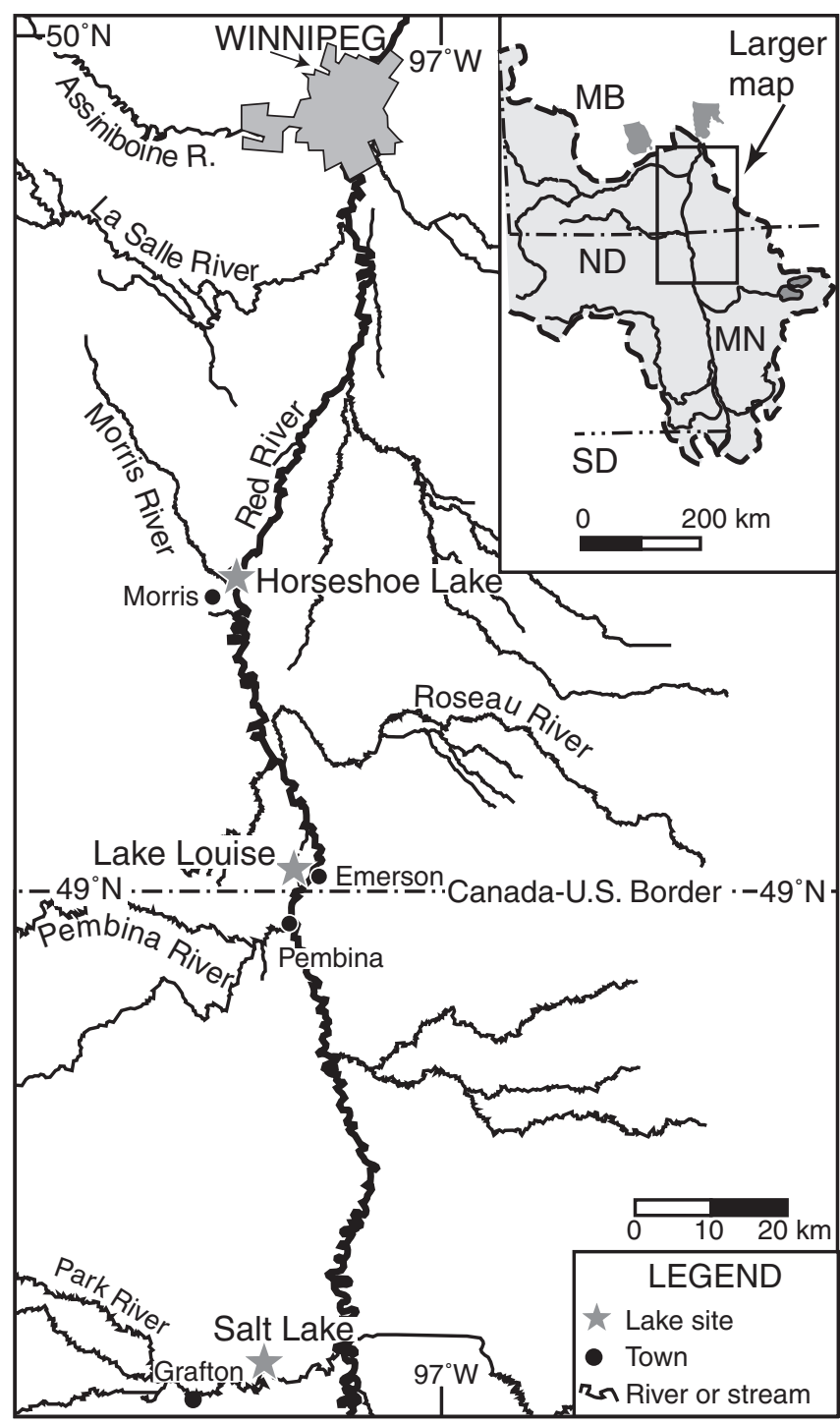

FIGURE 1. Location map showing Horseshoe Lake, Lake Louise and Salt Lake within the Red River valley. The inset map shows the Red River watershed.

Carte de localisation des lacs Horseshoe, Louise et Salt dans la vallée de la rivière Rouge. L'encadré montre le bassin-versant de la rivière Rouge.

FIGURE 2 Study sites with dots indicating approximate coring location at each lake. (A) An oblique view of Horseshoe Lake, surrounded by agricultural field and riparian forest. (B) An oblique view of Lake Louise, surrounded by agricultural fields and stands of deciduous and coniferous trees. (C) An aerial photograph showing Salt Lake outlined by a dashed line (United States Geological Survey aerial photograph taken on September 9, 1997).

Sites d'étude illustrant la position approximative des sites de carottage pour chacun des lacs. (A) Vue oblique du lac Horseshoe, entouré de champs de culture et de forêt riveraine. (B) Vue oblique du lac Louise, entouré de champs de culture et de peuplements de feuillus et de conifères. (C) Photographie aérienne du lac Salt, encerclé par une ligne pointillée (Photographie aérienne du United States Geological Survey prise le 9 Septembre 1997).
Lacustrine sediments in all three lake basins are derived from authigenic deposition of biological remains, sediment run-off from the surrounding fields, and deposition of Red River suspended sediment during high river stages. Several short cores, taken in the early summer of both 1997 and 1999, showed freshly deposited (uncompacted) flood sediments. The deposits at Horseshoe Lake measuring $3.0 \mathrm{~cm}$ in 1997 and $1.5 \mathrm{~cm}$ in 1999 while at Lake Louise a $1.5 \mathrm{~cm}$ deposit aggraded during the 1997 flood.
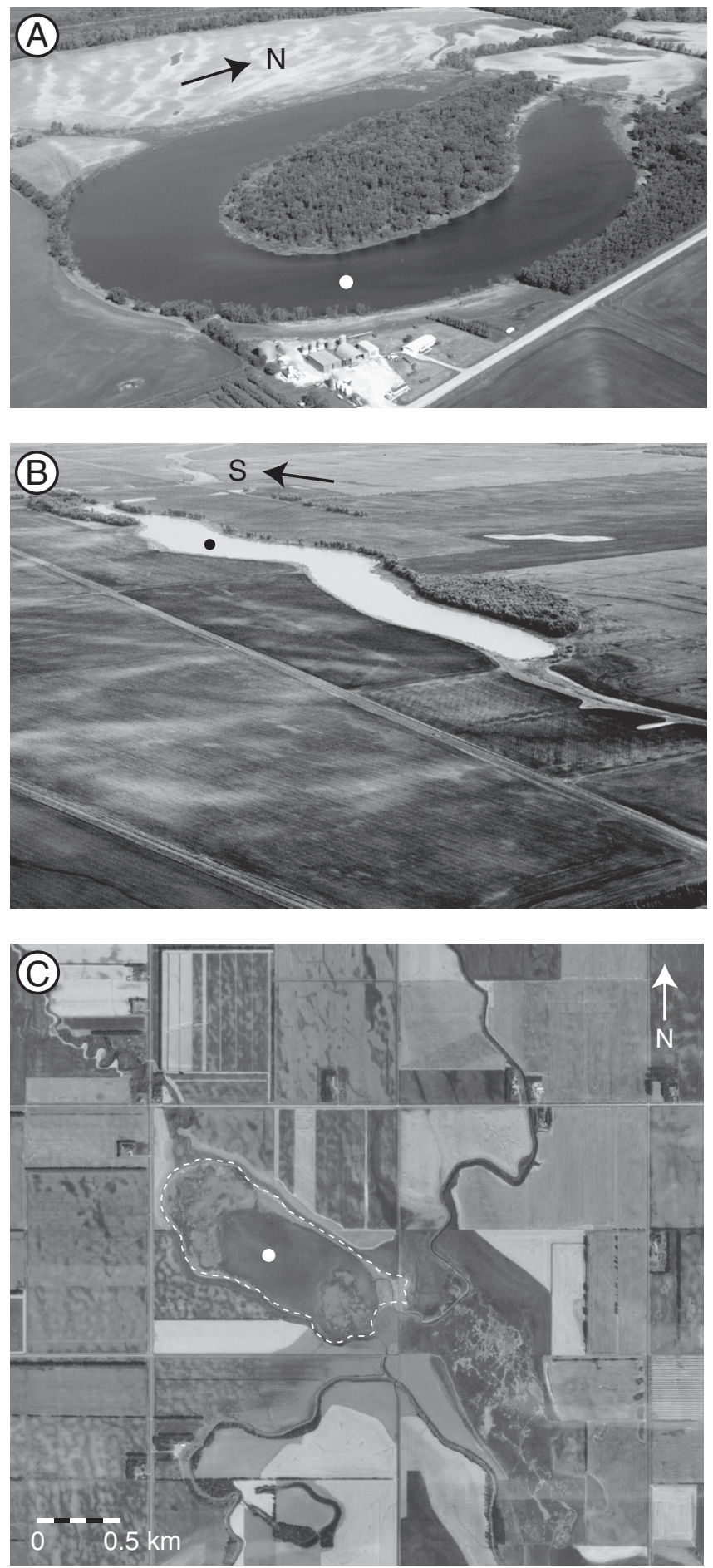


\section{METHODS}

Livingstone cores were collected from Horseshoe Lake, Lake Louise and Salt Lake on March $1^{\text {st }}$ and March $2^{\text {nd }}, 2000$. The recovered sediment cores were, respectively, 84, 34 and $123 \mathrm{~cm}$ long. The cores were split, logged and sampled in June, 2000, as described by Medioli (2001).

One-cubic centimetre pollen subsamples were collected every $5 \mathrm{~cm}$ downcore in the Horseshoe Lake and Salt Lake cores. No pollen samples were collected from Lake Louise as a pollen stratigraphy already exists for this lake (Brooks and Grenier, 2001). Samples were initially treated with dilute $\mathrm{HCl}$ $(10 \%)$ to remove carbonates from the highly calcareous sediments. They were then processed by standard acid digestion with $\mathrm{HF}$ and $\mathrm{HCl}$ followed by acetolysis (Faegri and Iversen, 1964). Lycopodium spore tablets of known concentrations were added to the samples in order to determine the pollen concentrations as grains per cubic centimetre of sediment. Pollen percentages are based on counts of at least 200 tree, shrub and herbaceous pollen (excluding aquatic plant pollen). All pollen data were input into TILIA and TILIAGRAPH (Grimm, 1991).

Diatom subsamples $\left(0.5 \mathrm{~cm}^{3}\right.$ each $)$ were collected and examined at $2 \mathrm{~cm}$ intervals from all three cores. Samples were freeze-dried and prepared according to standard procedures (Batterbee, 1986; Wilson et al., 1996). All diatoms were identified to the lowest possible taxonomic level and taxonomy following Krammer and Lange-Bertalot (1986-1991), Germain (1981) and Schrader and Gersonde (1978). Only diatom species that reached $>1 \%$ in at least one sample (per lake core) were considered in the analysis. For each slide 300 specimens were counted; when samples were too scarce the entire slide was counted. Species identification was frequently inhibited by the abundance of siliceous silt- and clay-sized sediment particles in the samples. Species ecological tolerances are based on a number of sources including Patrick and Reimer (1966, 1975). All diatom slides are archived at PEARL, Department of Biology, Queens University, Kingston, Ontario.

For all three lake cores, thecamoebian samples were collected at $2 \mathrm{~cm}$ intervals, washed over stacked 45 and $250 \mu \mathrm{m}$ sieves to remove the fine silt/clay fraction, as well as large organic particles, and then placed in a $30 \%$ ethanol solution. The 45-250 $\mu \mathrm{m}$ size fraction was analyzed and at least 300 specimens were counted per sample, or if the specimens were scarce, the entire assemblage was counted. Identifications are based on Medioli and Scott (1983) and Burbidge and Schröder-Adams (1998). Samples are archived in a $30 \%$ ethanol solution at the Geological Survey of Canada, Ottawa.

Sediment samples, collected at $2 \mathrm{~cm}$ intervals, were submitted to Flett Analytical for ${ }^{210} \mathrm{~Pb}$ analysis. Organic materials were collected from all three cores but only two macrofossil samples were substantial enough for AMS dating (Table I). At Horseshoe Lake a Scirpus fluviatilis stem was sampled at $84 \mathrm{~cm}$ depth and yielded a date of $780 \pm 50 \mathrm{BP}$ (Beta-151988) or 740-670 cal BP (Stuiver et al. 1998; Talma and Vogel 1993). A Scirpus fluviatilis stem was collected at $27 \mathrm{~cm}$ depth in Salt Lake core, and yielded a modern radiocarbon age.

\section{RESULTS}

\section{POLLEN}

Pollen analysis of the Horseshoe Lake core reveals two distinct zones (Fig. 3A). Zone I extends from the bottom of the core at $84 \mathrm{~cm}$ to $40 \mathrm{~cm}$ depth whereas Zone II extends from $40 \mathrm{~cm}$ to the top of the core. In Zone I the pollen assemblage consists of abundant tree pollen (Quercus: $30-40 \%$ and Ulmus: $5-9 \%$ ) similar to the tree taxa observed in the modern Red River riparian forest. Herbaceous pollen (Gramineae: 5\%, Ambrosia: 7-12\%, Artemisia: 4-9\% and Chenopodiineae: 1-4\%) are also present, and represent a tall grass prairie habitat (Jacobson and Engstrom, 1989). The beginning of Zone II is marked by a decline in tree pollen (mainly Quercus and UImus) and an associated rise in herbaceous pollen (e.g., Gramineae, especially cereal grasses, Tubulifloreae and Ligulifloreae), as well as weed species (Ambrosia, Artemisia and Chenopodiineae). The transition from Zone I to Zone II coincides with a rise in Ambrosia and the first occurrence of the weed species Salsola and Rumex at $40 \mathrm{~cm}$ depth. The highest abundance of Salsola and Ambrosia occurs at $30 \mathrm{~cm}$ depth (Fig. 3A). A slight decline in herbaceous pollen and a recovery in Quercus to near Zone I levels occur at the top of the core.

Two distinct pollen zones are also identified in the Salt Lake core (Fig. 4A). Zone I (from 123 to $100 \mathrm{~cm}$ depth) is dominated by tree pollen (Quercus: $10-20 \%$ and Pinus: $8-9 \%$ ). Herbaceous pollen (Ambrosia: 10\%, Chenopodiineae: 7-20\%, Artemisia: 5-8\% and Tubulifloreae: 5-7\%) are also common. Zone II spans from 100 to $0 \mathrm{~cm}$ depth and consists of herbaceous pollen (Ambrosia: 9-30\%, Gramineae: 1-6\%, Crucifereae: up to 3\%, Artemisia: 2-8\%, Chenopodiineae: 4-21\%), exotic weed species (Salsola: 0-4\%, Brassica: 0-2\%, Rumex: $0-1 \%)$ and cereal grasses (0-10\%) which increase in abundance throughout the zone. A slight increase in tree pollen (especially Quercus) occurs near the top of Zone II. Salsola first appears at $70 \mathrm{~cm}$ and is associated with the second rise in Ambrosia (up to 21\%) and Crucifereae (up to 3\%).

\section{DIATOMS}

Diatom and thecamoebian assemblages are subdivided into zones based on the pollen zonation described above. The fluc-

TABLE I

Summary of radiocarbon ages from the coring locations

\begin{tabular}{|c|c|c|c|c|c|c|c|}
\hline $\begin{array}{l}\text { Sample lab } \\
\text { number }\end{array}$ & Core location & Latitude & Longitude & Depth $(\mathrm{cm})$ & Material dated & $\begin{array}{c}{ }^{13} \mathrm{C} /{ }^{12} \mathrm{C} \text { ratio } \\
\text { (\%) }\end{array}$ & ${ }^{14} \mathrm{C}$ age \\
\hline Beta-151988 & Horseshoe Lake & $49.339^{\circ} \mathrm{N}$ & $97.323^{\circ} \mathrm{W}$ & $78-84$ & Scirpus fluviatilis stem & -24.2 & $790 \pm 50$ \\
\hline Beta-151989 & Salt Lake & $48.480^{\circ} \mathrm{N}$ & $97.290^{\circ} \mathrm{W}$ & $26-27$ & Scirpus fluviatilis stem & -23.7 & Modern \\
\hline
\end{tabular}




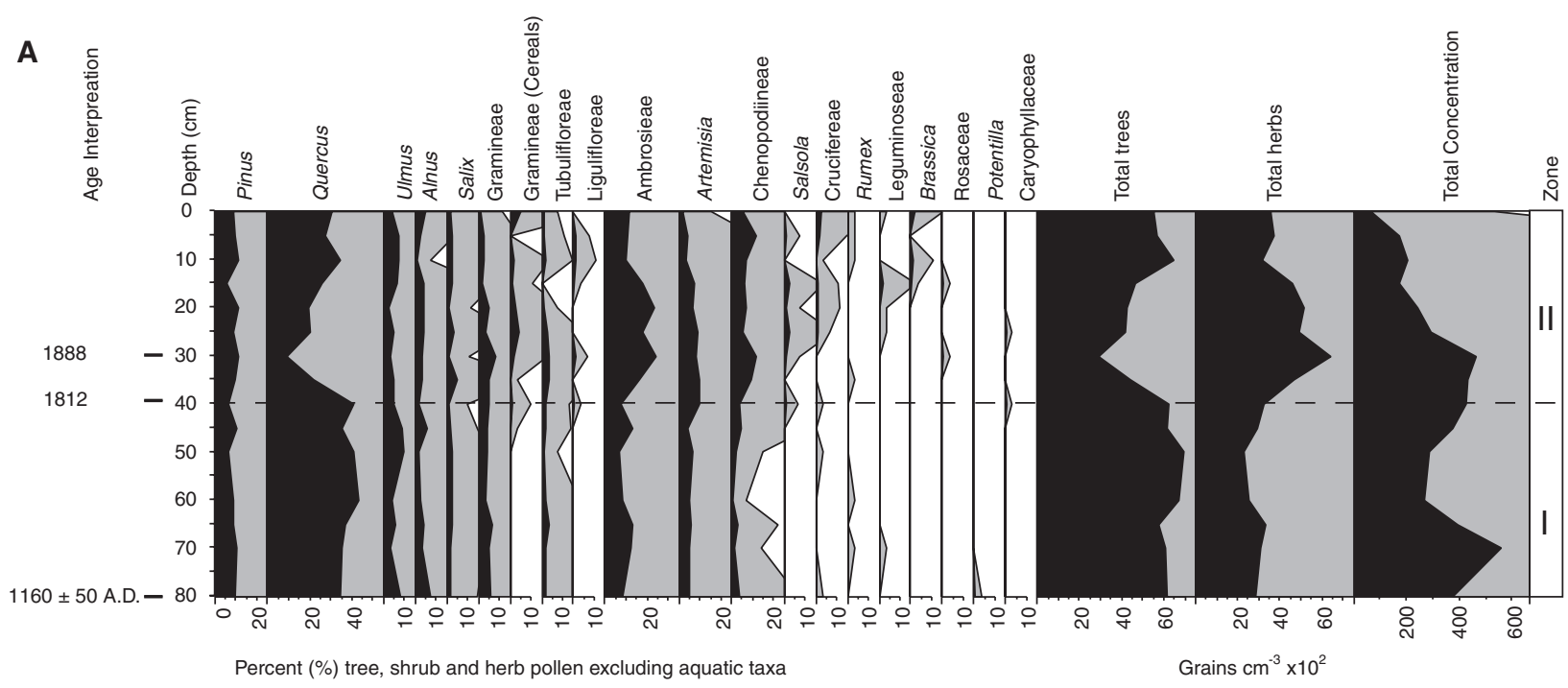

B

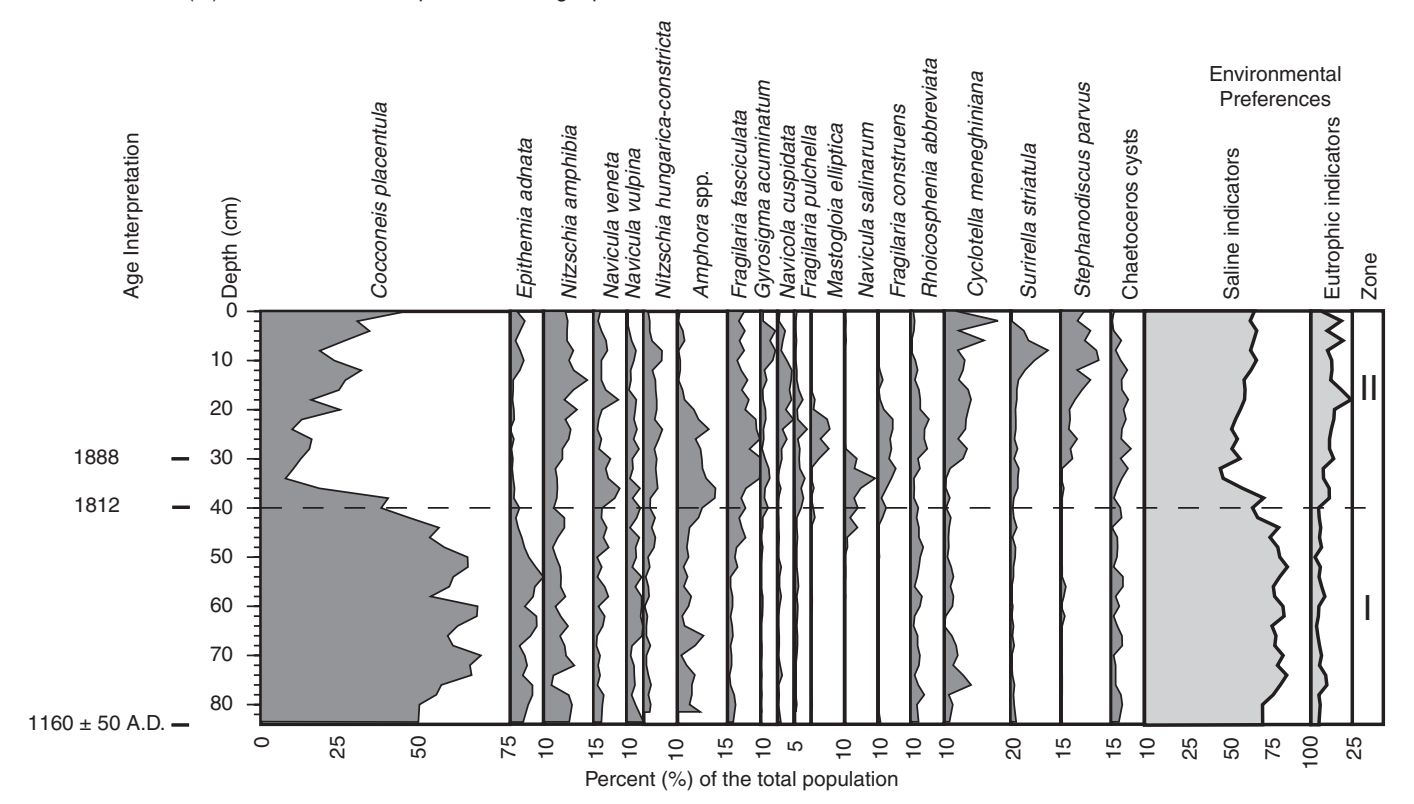

C

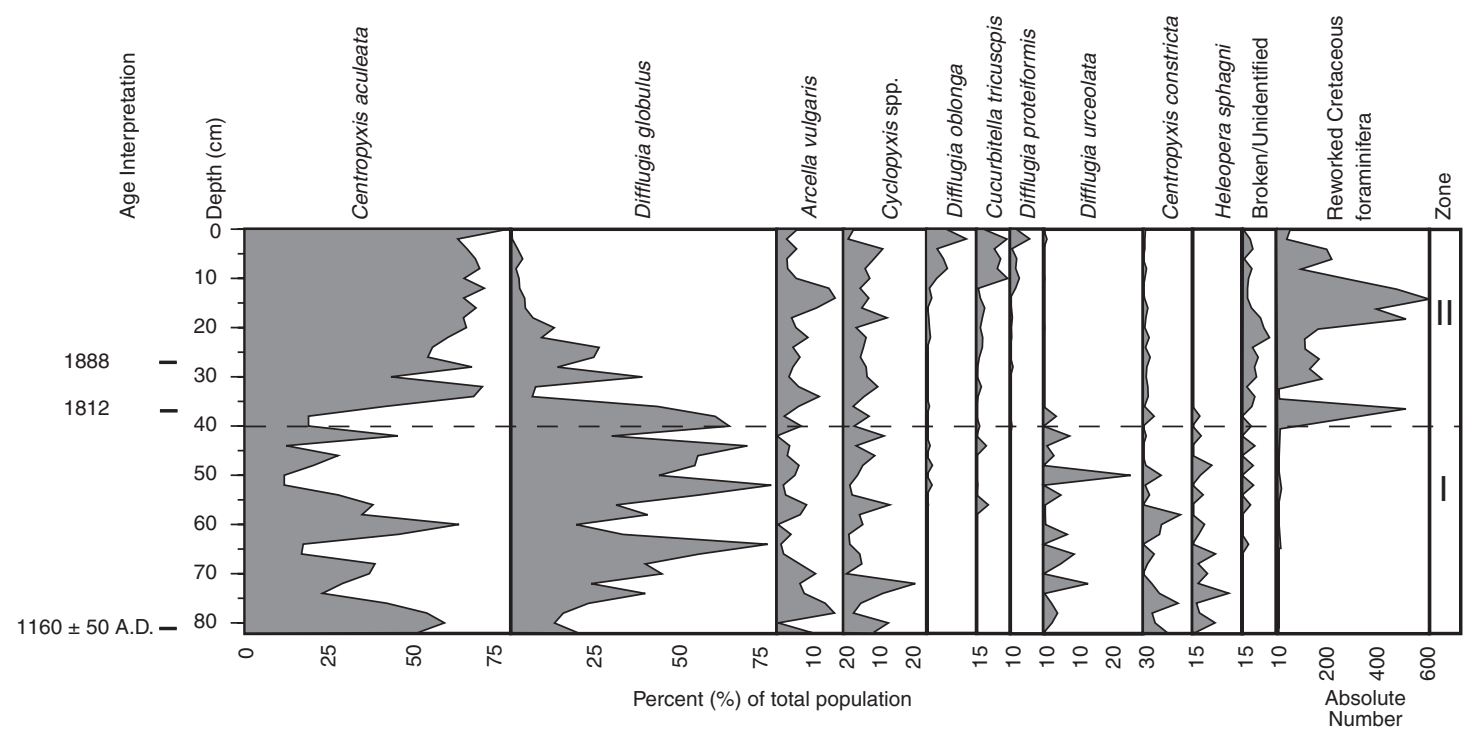

FIGURE 3. Horseshoe Lake pollen, diatom and thecamoebian assemblages showing interpreted and radiocarbon dates, as well as the preand post-settlement periods (Zones I and II, respectively). (A) Pollen diagram of pertinent taxa with gray shaded area at $5 \mathrm{X}$ exaggeration. (B) Diatom assemblage diagram with environmental preferences. (C) Thecamoebian assemblages.
Assemblages polliniques, de diatomées et de thécamoébiens du lac Horseshoe illustrant les âges interprétés et les âges au radiocarbone, ainsi que les périodes de pré- et de post-peuplement (Zones I et II, respectivement). (A) Diagramme pollinique du taxon pertinent, où les zones ombragées sont exagérées 5 fois. (B) Diagramme d'assemblage des diatomées avec les préférences environnementales. (C) Diagramme d'assemblage des thécamoébiens. 
A

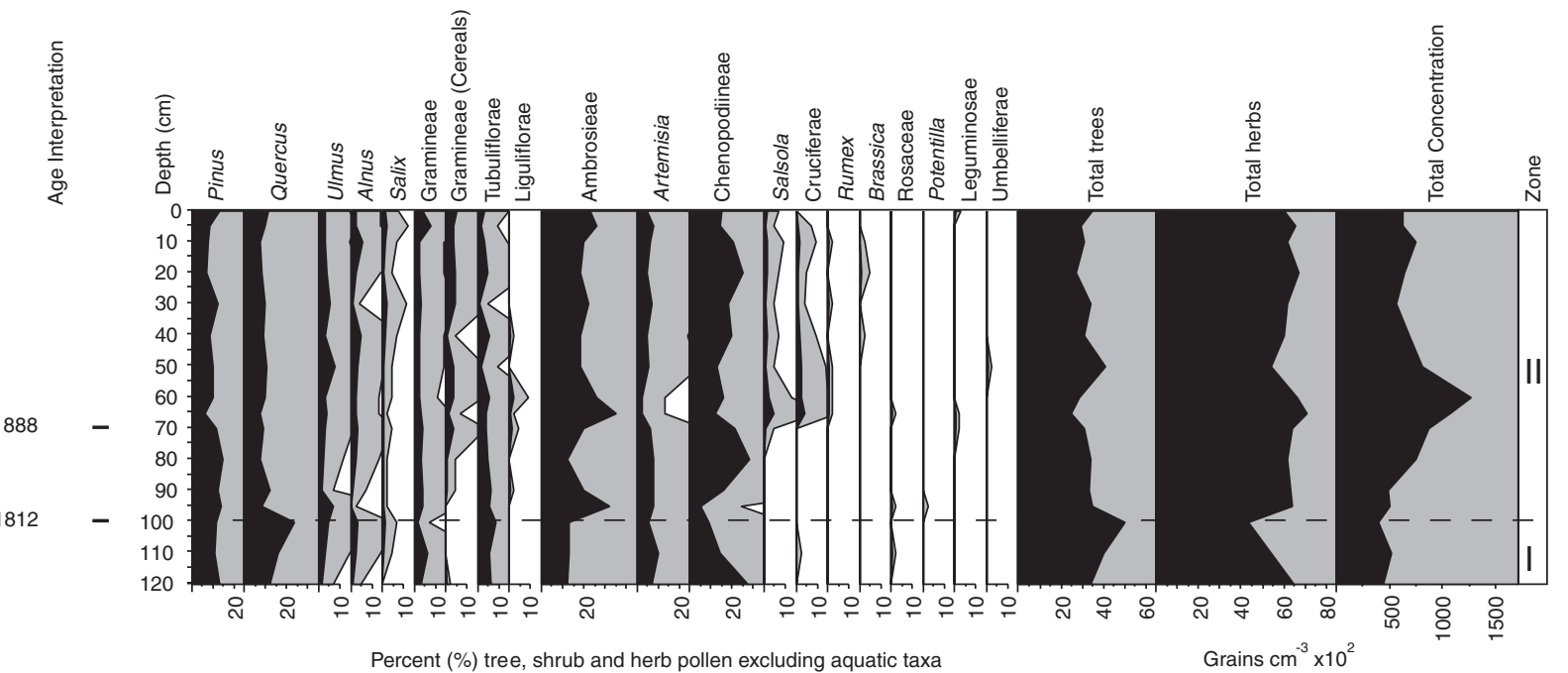

B

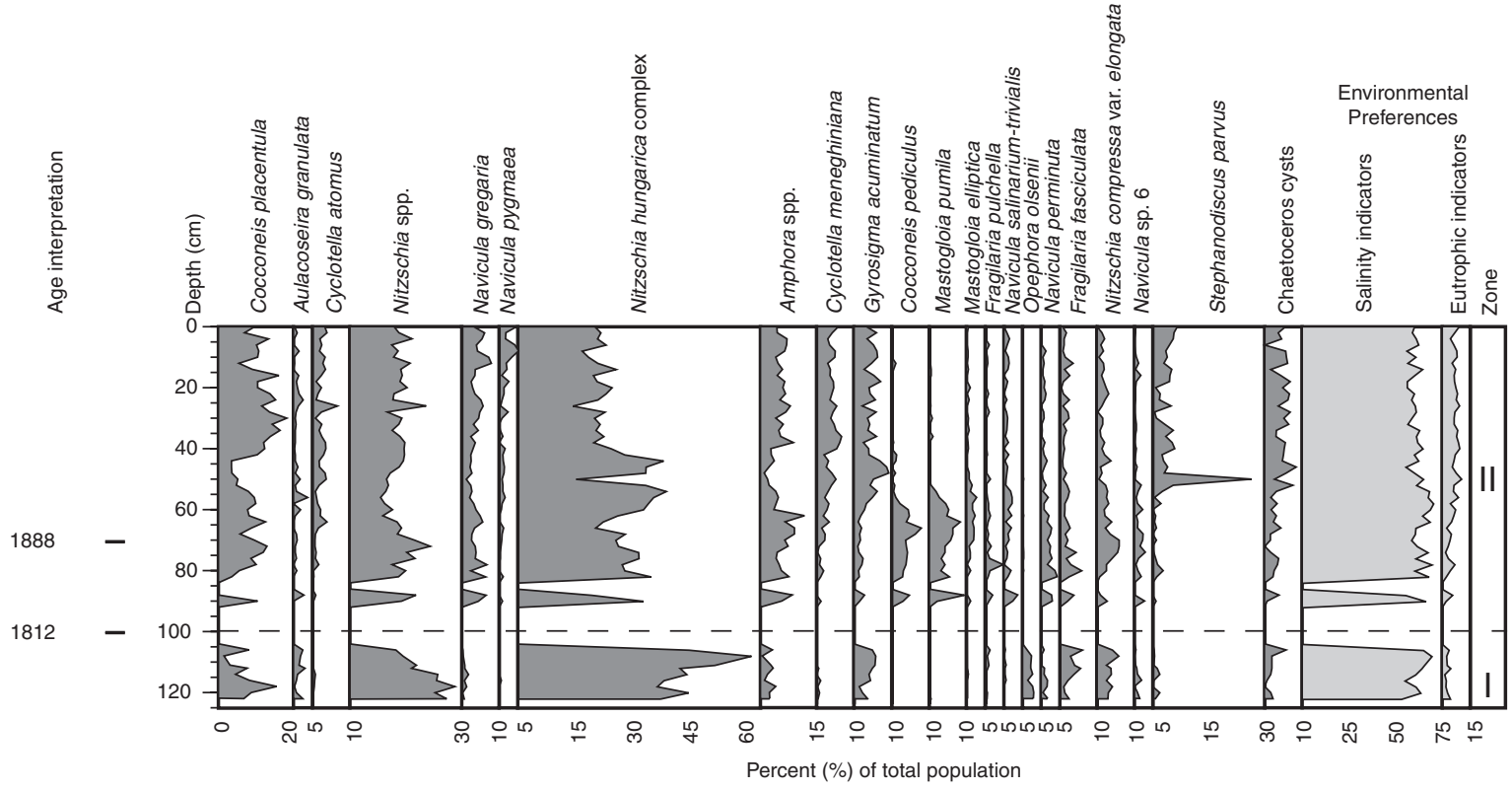

C

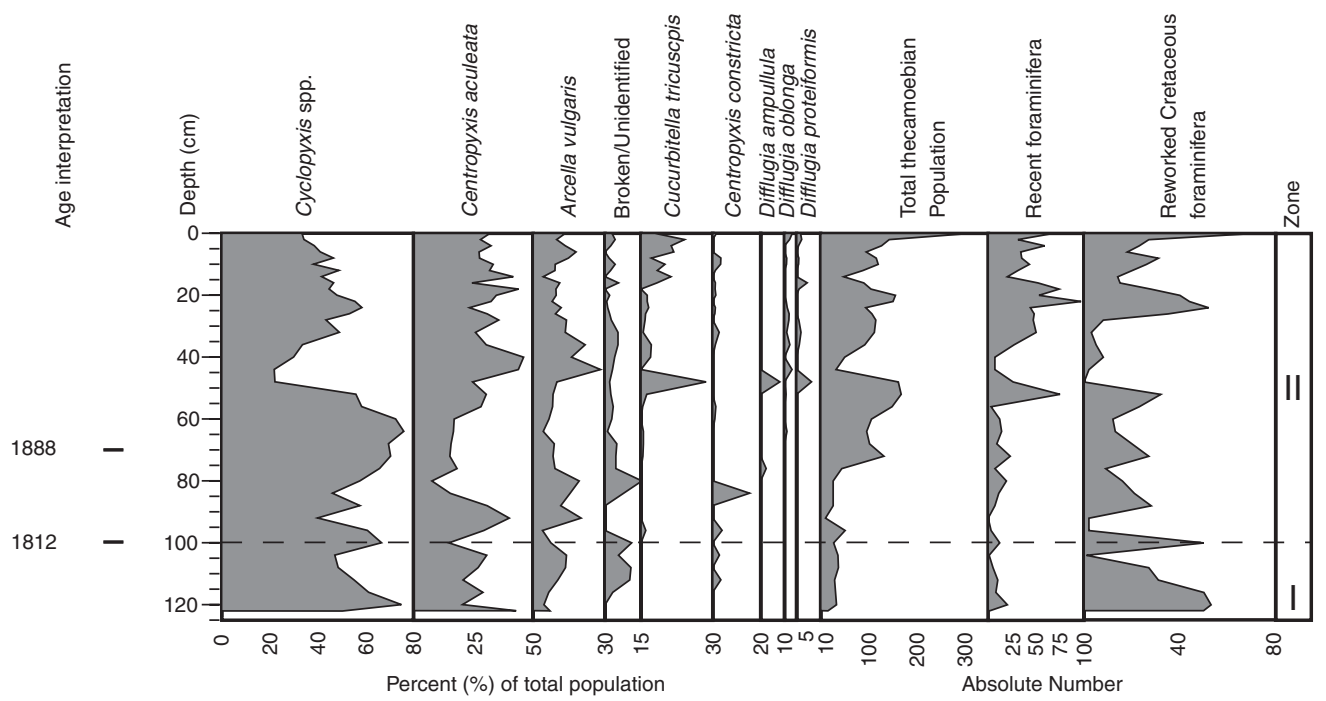

FIGURE 4. Salt Lake pollen, diatom and thecamoebian assemblages showing interpreted dates and pre- and post-settlement periods (Zones I and II, respectively). (A) Pollen diagram of pertinent taxa, gray shaded area at $5 \mathrm{X}$ exaggeration. (B) Diatom assemblages with environmental preferences. (C) Thecamoebian assemblages.

Assemblages polliniques, de diatomées et de thécamoébiens du lac Salt illustrant des âges interprétés et les périodes de pré- et de postpeuplement (Zones I et II, respectivement). (A) Diagramme pollinique du taxon pertinent, où les zones ombragées sont exagérées 5 fois. (B) Diagramme d'assemblage des diatomées avec les préférences environnementales. (C) Diagramme d'assemblage des thécamoébiens. 
tuations in the diatom assemblages seen in Figure 3B are primarily due to the decline in Cocconeis placentula and the rise in Cyclotella meneghiniana. Cyclotella meneghiniana, a halophilic diatom (Germain, 1981; Krammer and Lange-Bertalot, 1991), increases in abundance from $<5 \%$ in Zone I to $>10 \%$ in Zone II. Zone I is dominated by Cocconeis placentula (45-65\%) - an epiphytic and euryhaline species (Germain, 1981), Nitzschia amphibia (3-8\%), Epithemia adnata (2-8\%), Amphora libyca ( $5 \%)$ and Cyclotella meneghiniana $(<5 \%)$. Zone II is dominated by Cocconeis placentula (6-35\%) and Cyclotella meneghiniana (5-12\%), as well as Nitzschia amphibia $(4-13 \%)$, with smaller concentrations of Stephanodiscus parvus (3-11\%), Fragilaria fasciculata (3-10\%), Nitzschia veneta (1-6\%), Suririella striatula (up to 5\%) and Fragilaria construens (2-5\%).

The Lake Louise diatom assemblages are dominated by Cocconeis placentula (21-41\%), Epithemia adnata (7-12\%),
Amphora libyca (3-9\%), Stephanodiscus parvus (1-10\%), Gyrosigma acuminatum (1-4\%), Nitzschia amphibia ( 5\%), Rhopalodia gibba (1-4\%), with a peak in Cyclotella comta (from $0 \%$ to $9 \%$ ) near the base of the core (Fig. $5 \mathrm{~A}$ ). This assemblage appears to correspond to Brooks and Grenier's (2001) upper pollen zone which occurred from 0 to $30 \mathrm{~cm}$ depth.

Two distinct diatom assemblages are identified in the Salt Lake core; these are separated by a section devoid of diatoms (Fig. 4B). Zone I is dominated by the Nitzschia hungarica complex (40-60\%), Cocconeis placentula (1-16\%) and Nitzschia libetruthii (5-20\%) with lesser amounts of Gyrosigma acuminatum (5-8\%), Fragilaria fasciculata (5-8\%) and Nitzschia compressa (5-8\%). Zone II is dominated by Nitzschia hungarica complex (15-35\%) and Cocconeis placentula (3-18\%), with lesser amounts of Stephanodiscus parvus (5-10\% with a $30 \%$ spike at $50 \mathrm{~cm}$ depth), Nitzschia libetruthii (5-10\%), Cyclotella

A

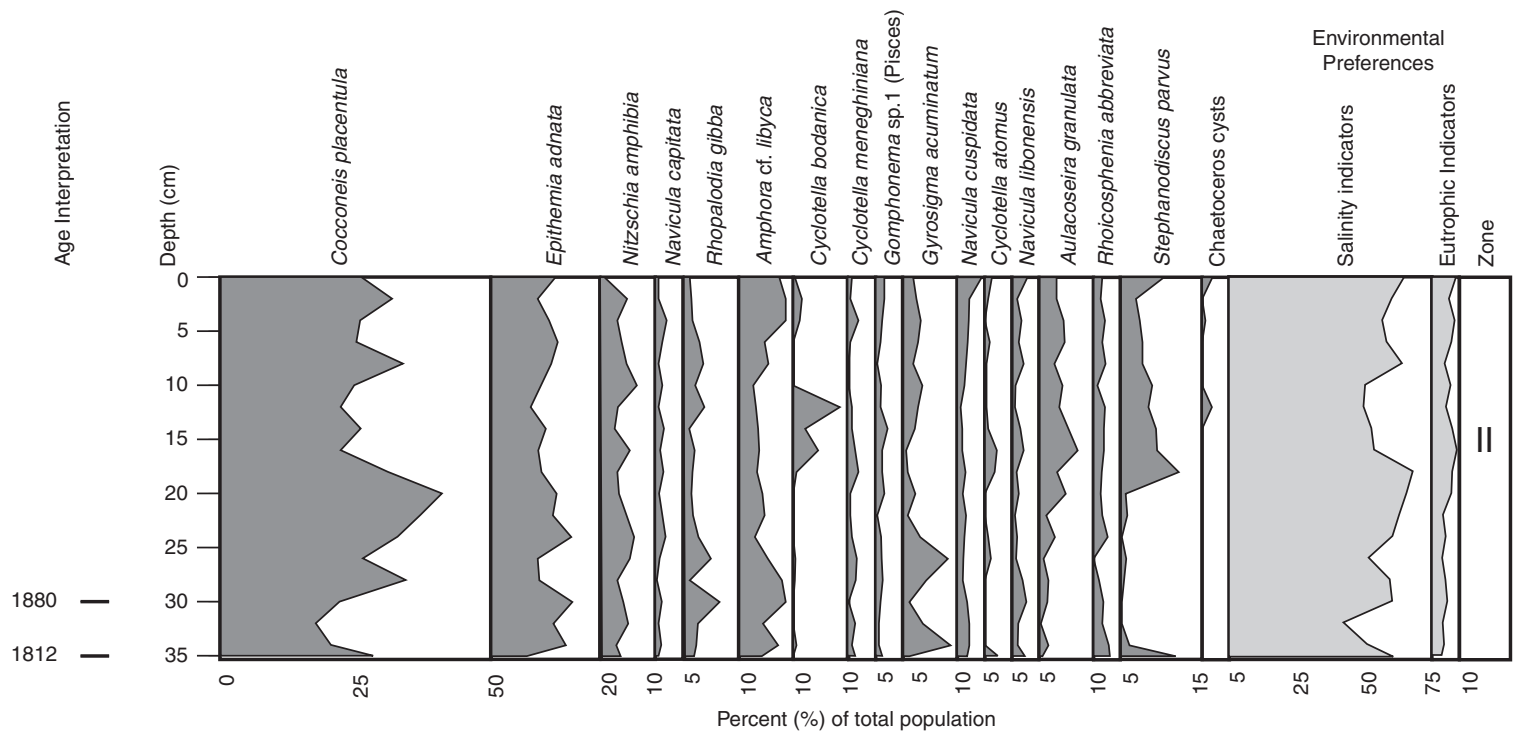

B

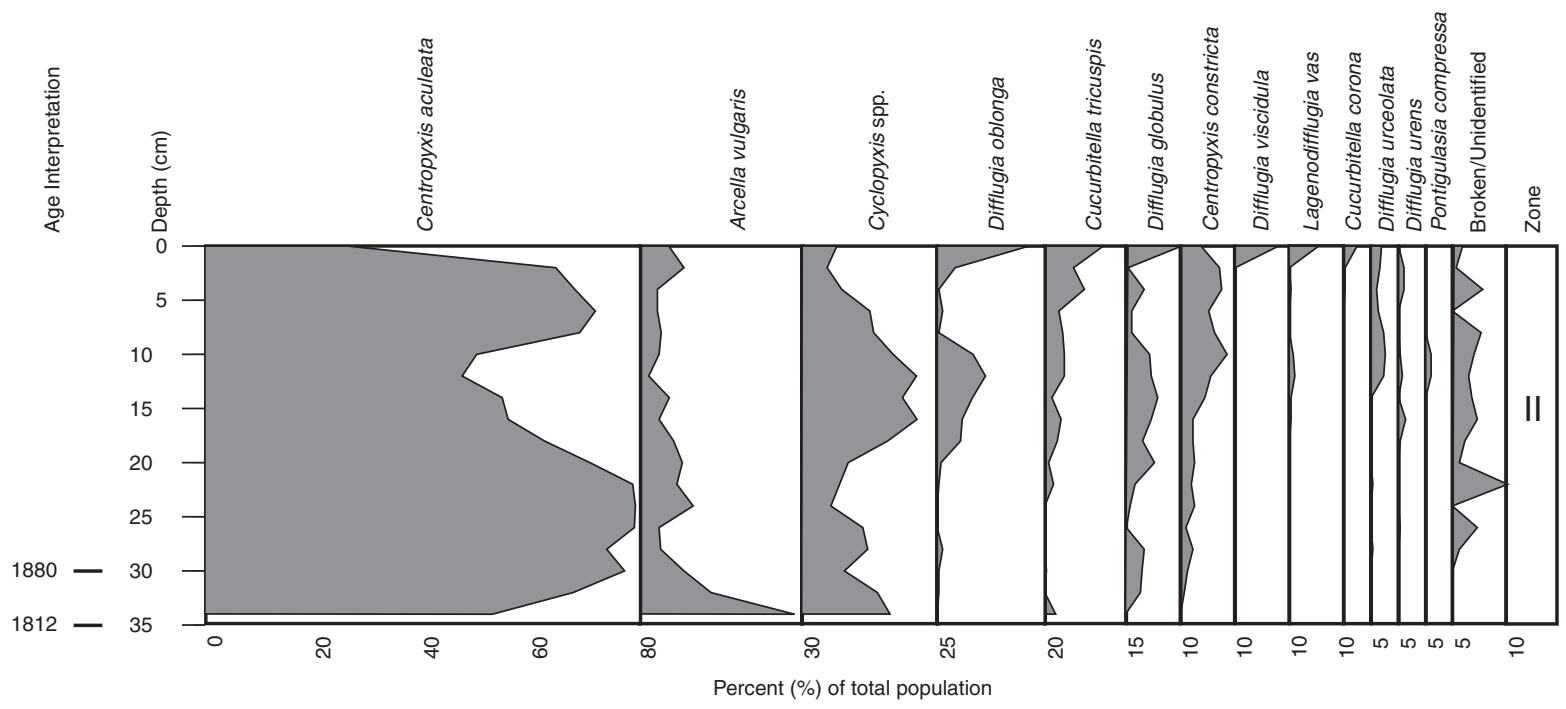

FIGURE 5. Lake Louise diatom and thecamoebian assemblages with dates and zonal boundaries based on Brooks and Grenier (2001). (A) Diatom assemblages with environmental preferences. (B) Thecamoebian assemblages.
Assemblages des diatomées et des thécamoébiens du lac Louise établis à partir des dates et des limites zonales établies par Brooks et Grenier (2001). (A) Diagramme d'assemblage des diatomées avec les préférences environnementales. (B) Diagramme d'assemblage des thécamoébiens. 
meneghiniana (5-8\%), Gyrosigma acuminatum (5-10\%) and Nitzschia gregoria (5-10\%). The major difference between the two zones is a decreased abundance of the Nitzschia hungarica complex (from 45-60\% to 15-30\%) and Nitzschia libetruthii from Zone I into Zone II. In addition, Stephanodiscus parvus increases from Zone I $(<5 \%)$ to Zone II $(>5 \%)$ and slight increases in Cocconeis pediculus (5-10\%) and Mastogloia pumila (5-10\%) occur between 50 and $90 \mathrm{~cm}$ depth.

\section{THECAMOEBIANS}

The Zone I thecamoebian assemblage in Figure $3 \mathrm{C}$ is dominated by Difflugia globulus (55-78\%). Centropyxis aculeata (12-39\%), Arcella vulgaris (2-14\%), Cyclopyxis spp. (1-9\%) and Centropyxis constricta $(\sim 1 \%)$ are also abundant. Broken thecamoebian tests were observed in this zone and are more abundant than in Zone II. Reworked Cretaceous foraminifera, when present, occur in low numbers ( $<15$ per sample). Zone II is dominated by Centropyxis aculeata (42-80\%) with an abundance of Arcella vulgaris (2-13\%), Cyclopyxis spp. (3-12\%), Difflugia oblonga (1-6\%), and Cucurbitella tricuspis (1-9\%), an eutrophic indicator (Medioli and Scott, 1988), which is especially abundant near the top of the core. Reworked Cretaceous foraminifera are abundant in Zone II (up to 500 individuals per sample).

In the Lake Louise core, the thecamoebian assemblages only span pollen Zone II (Fig. 5B) which is dominated by Centropyxis aculeata (26-80\%), Cyclopyxis spp. (8-16\%), Difflugia oblonga (1-17\%), Arcella vulgaris (2-29\%), Cucurbitella tricuspis (1-11\%) and Phryganella spp. (1-2\%). The top $20 \mathrm{~cm}$ of the deposits show a large increase in Cucurbitella tricuspis and Difflugia oblonga (from $<1 \%$ to $>5 \%$ for both taxa). Reworked Cretaceous foraminifera are sparse to absent.

Two distinct thecamoebian assemblages are observed in Salt Lake (Zone I from 123 to $100 \mathrm{~cm}$ depth and Zone II from 100 to $0 \mathrm{~cm}$ depth) and are defined by changes in total test concentration, as well as the presence of modern euryhaline foraminifera (Fig. 4C). Zone I is dominated by Cyclopyxis spp. (47-67\%), Centropyxis aculeata (15-43\%) and Arcella vulgaris (5-14\%). Zone II is dominated by Cyclopyxis spp. (33-70\%), Centropyxis aculeata (24-46\% from the surface to $57 \mathrm{~cm}$ and 8-40\% between 61-100 $\mathrm{cm}$ ) and Arcella vulgaris (9-20\%), as well as Cucurbitella tricuspis (2-27\%) in the top $50 \mathrm{~cm}$ of the core. In addition, one species of euryhaline foraminifera, Trochammina macrescens cf. polystoma, is also common in the Salt Lake deposits (up to 70 specimens per sample). At $50 \mathrm{~cm}$ depth there is a dramatic decrease in Cyclopyxis spp. (from 56 to $22 \%$ ) and an increase in Trochammina macrescens cf. polystoma (from 26 to 75 individuals per sample; see Fig. 4C).

\section{DISCUSSION}

\section{CHRONOLOGY AND TERRESTRIAL LANDSCAPE CHANGE}

The pollen stratigraphy provides excellent chronological control on the last 200 years of sedimentation in these lake cores. The pre-settlement landscape of the Red River valley consisted mostly of tall grass prairie with riparian forests surrounding the Red River and its floodplain lakes (Ross, 1856; Warkentin and Ruggles, 1970). During this period, herbaceous pollen (Chenopodiineae, Ambrosia, Artemisia, Tubulifloreae, Gramineae) were abundant, whereas weed taxa (i.e., Ambrosia, Crucifereae and Chenopodiineae) were less common than in the present-day landscape (Figs. 2A, 5A). The abundance of Quercus and other tree pollen (Pinus, Ulmus, Alnus and Salix) indicates an abundant and mature riparian forest, consistent with Dawson's (1875) description of the region. The pollen spectra from Horseshoe Lake (Fig. 3A) also corroborate firsthand descriptions of the region and are consistent with landscape reconstructions, based on 1871-1895 Dominion land survey maps, by Hanuta (2001), namely the presence of a rich riparian forest along the river and the lake. The composition of the forest and the tall grass prairie indicated by the pollen spectra is similar to that found in other studies from the eastern Northern Great Plains (Shapley et al., 2005). The pollen spectra from Salt Lake (Fig. 4A) also agree well with the above.

In the Horseshoe Lake core, a rise in Ambrosia and Rumex at $40 \mathrm{~cm}$ marks the transition from Zone I to Zone II while in the Salt Lake core a similar transition occurs at $100 \mathrm{~cm}$. This transition is marked by a sharp decline in tree pollen and is dated at $\sim 1812$, the year Red River Settlement was established and immigrant settlers began arriving into the Red River basin. Brooks and Grenier (2001) also report an increase in herbaceous pollen (Artemesia, Ambrosia, Gramineae, Chenopodiineae, Ligulifloreae, and Crucifereae) at the transition between the two zones which they associate with the onset of settlement and the introduction of agriculture (Brooks and Grenier, 2001). Their upper zone spans the top $30 \mathrm{~cm}$ of the core, beginning with a sharp rise in Ambrosia at $30 \mathrm{~cm}$, a decrease in tree pollen (Quercus, Pinus, Ulmus, Betula and Populus), and a rise in cereal pollen which they correlate with riparian deforestation and European settlement in the Emerson area between the late 1870 s and the early 1880s (McClelland, 1975), a period in which the population of southern Manitoba increased more than sixfold (Travel Manitoba, 2005). We also attribute this decline to the arrival of settlers and the subsequent riparian deforestation (Dawson, 1875; Macoun, 1882).

Another key chronological fix on the pollen spectra is the first arrival of the exotic Russian Thistle (Salsola) whose first North American occurrence is dated at 1873 (Dewey, 1895; Beatley, 1973). The introduction of Salsola has been correlated to the arrival of other Eurasian weeds (including Brassica), which in turn are associated with the cultivation of grains such as wheat, rye and oats (classified as cereal grasses on Figs. 3A, 4A) in the North American mid-west. Jacobson and Engstrom (1989) report the arrival of Salsola in North Dakota by 1888-1891. Once the plant arrived at the Red River, it would have spread quickly downstream and throughout the watershed. Anderson (2003) and Lewis et al. (2001) estimated Salsola arrived into the Manitoba portion of the Red River valley in 1888. Salsola pollen first appears at $30 \mathrm{~cm}$ depth in Horseshoe Lake and at $70 \mathrm{~cm}$ depth in Salt Lake and is associated with the second rise in Ambrosia, as well as an increase in cereal grasses. Although Salsola was not reported by Brooks and Grenier (2001) at Lake Louise, a second Ambrosia peak was observed at $28 \mathrm{~cm}$ depth and estimated to be 1880 . 
During the early part of Zone II (1812-1888), a decline in tree pollen in all three lakes reflects progressive deforestation and wetland drainage. Small-scale agriculture begins in the early 1800 s and increases throughout the late $19^{\text {th }}$ and $20^{\text {th }}$ centuries (Macoun, 1882). As a consequence, weed and cereal grass pollen (e.g., Salsola, Ambrosia, Crucifereae and Chenopodiineae) appear and/or increase during this settlement period. A steady increase in tree pollen during the $20^{\text {th }}$ century portion of Zone II, subsequent to the discontinuation of steamboats that used wood for fuel and the arrival of the railroad (Carlson and Masterson, 1950; Macoun, 1882; McClelland, 1975), reflects riparian forest regrowth. A slight decline in herbaceous pollen at the top of the Horseshoe Lake core may be due to the introduction of herbicides.

Overall, the pollen successions we observe in Horseshoe and Salt lakes agree well with the pollen successions from Lake Louise, Manitoba (Brooks and Grenier, 2001), Devils Lake (Jacobson and Engstrom, 1989) and Waubay Lake (Shapley et al., 2005), North Dakota. The pre-settlement period is dominated by the herbaceous taxa of Ambrosia, Artemisia, and Gramineae at Horseshoe Lake and by Ambrosia, Chenopodiineae and Artemisia at Salt Lake. By comparison, at Devils Lake Artemisia, wild grasses and Ambrosia dominated. Quercus and Pinus are the dominant tree pollen in both the Red River valley lakes and the Devils Lake pollen spectra. A decline in Quercus is common to the post-settlement period throughout the region.

Medioli (2001) reports the results of ${ }^{210} \mathrm{~Pb}$ dating on sediments from the three lakes. The difference in background ${ }^{210} \mathrm{~Pb}$ and surface activity, however, is low and the ${ }^{210} \mathrm{~Pb}$ data do not show a constant rate of decay, as would be expected from a constant rate of sedimentation. As a result CRS (Constant Rate of Supply) modeling (Appleby and Oldfield, 1978) provides unreliable data for Horseshoe Lake and is inconclusive for both Lake Louise and Salt Lake. The lakes are inundated periodically by sediment-laden Red River flood waters which likely results in episodic deposition into the basins (see Figs. 3-4 in Medioli and Brooks, 2003). This pattern of nonlinear sedimentation pattern may explain why ${ }^{210} \mathrm{~Pb}$ dating was unsuccessful, and is supported by Jacobson and Engstrom's (1989) work on prairie lakes.

\section{LAKE EUTROPHICATION}

In Zone I eutrophic diatom indicators are less abundant than in Zone II (Figs. 3B, 4B; Table II) both in Horseshoe Lake and Salt Lake. Thecamoebian populations are small and Cucurbitella tricuspis is absent, indicating oligotrophic to

TABLE ॥

Environmental preferences of selected taxa

\begin{tabular}{|c|c|c|c|}
\hline Microfossil group & Salinity & Eutrophy & Oligotrophy \\
\hline Diatoms & $\begin{array}{l}\text { Amphora acutisola } \\
\text { Amphora libyca } \\
\text { Amphora veneta } \\
\text { Cocconeis pediculus } \\
\text { Cocconeis placentula } \\
\text { Cyclotella atomus } \\
\text { Cyclotella meneghiniana } \\
\text { Epithemia adnata } \\
\text { Fragilaria fasciculata } \\
\text { Fragilaria pulchella } \\
\text { Mastigloia pumila } \\
\text { Navicula cuspidata } \\
\text { Navicula gregaria } \\
\text { Navicula pygmea } \\
\text { Navicula salinarum } \\
\text { Navicula veneta } \\
\text { Nitzschia hungarica } \\
\text { Rhiocosphenia abbreviata } \\
\text { Rhopalodia gibba } \\
\text { Stephanodiscus parvus } \\
\text { Surirella striatula }\end{array}$ & $\begin{array}{l}\text { Aulacoseira granulata } \\
\text { Cyclotella meneghiniana } \\
\text { Fragilaria pulchella } \\
\text { Navicula cuspidata } \\
\text { Navicula veneta }\end{array}$ & $\begin{array}{l}\text { Nitzschia lacuum } \\
\text { Pinnularia interrupta }\end{array}$ \\
\hline Thecamoebians & $\begin{array}{l}\text { Arcella vulgaris } \\
\text { Centropyxis aculeata } \\
\text { Centropyxis constricta }\end{array}$ & $\begin{array}{l}\text { Cucurbitella tricuspis } \\
\text { Difflugia oblonga } \\
\text { Difflugia proteiformis }\end{array}$ & $\begin{array}{l}\text { Centropyxis aculeata } \\
\text { Cyclopyxis spp. }\end{array}$ \\
\hline Foraminifera & Trochammina macrescens cf. polystoma & & \\
\hline
\end{tabular}


mesotrophic conditions (Figs. 3C, 4C; Table II). Furthermore, Difflugia globulus, indicative of low nutrient availability (Burbidge and Schröder-Adams, 1999), is the most abundant taxa in Zone I. This suggests oligotrophic lake conditions during the pre-settlement period.

In Zone II both thecamoebian populations and Cucurbitella tricuspis increase steadily. Cucurbitella tricuspis is especially abundant in the top $15 \mathrm{~cm}$ of Horseshoe Lake and Lake Louise (Figs. 3C, 5B; Table II) and in the top $50 \mathrm{~cm}$ of Salt Lake, most likely because of lake eutrophication associated with increased macrophyte growth during the growing season (Medioli and Scott, 1988; Scott et al., 2001). In both Horseshoe Lake and Salt Lake the eutrophic indicator species Cyclotella meneghiniana (Germain, 1981) increases up core, supporting the notion of an increase in lake nutrients through time. This is similar to results reported by Finkelstein et al. (2005). At Lake Louise Aulacoseira granulata and Stephanodiscus parvus increase between 18 and $20 \mathrm{~cm}$ depth while Cocconeis placentula decreases.

Medioli (2003) reports up core increases in potassium and phosphorus which coincide with the increases in Cucurbitella tricuspis and suggest increasing eutrophic conditions during Zone II in all three lakes. Burbidge and Schröder-Adams (1999) and Torigai et al. (2000) report similar changes in the upper sediments of Lake Winnipeg that are associated with increased nitrogen runoff. A sharp rise in thecamoebian population size between Zone I and II is indicative of increased nutrient availability (Kliza and Schröder-Adams, 1999). We attribute eutrophication to the introduction of chemical fertilizers and increased run off into the lakes brought on by the change in landscape from tall grass prairie to cultivated agricultural fields. This has been seen in other studies on the effect of deforestation, the onset of agriculture and the occurrence of lake eutrophication (Brugam et al., 2003; Dalton et al., 2005; Ekdahl et al., 2004; Finkelstein et al., 2005; Forrest et al., 2002; Wolin and Stoermer, 2005). In a study by Ekdahl et al. (2004), at Crawford Lake, Ontario, pre-European lake disturbance, brought about by 200 years of Iroquois settlement and corn cultivation, has permanently changed the limnological conditions of the lake despite abandonment of the site centuries ago. This suggests that limnological changes brought about by intensive agricultural practices can adversely affect lacustrine systems, as may be the case in the study lakes.

\section{LAKE WATER SALINITY}

The majority ( $>50 \%$ ) of the diatom taxa in all three lakes are adapted to living in freshwater environments with elevated salinity and/or conductivity (Figs. 3B, 4B, 5A). The taxa Cyclotella meneghiniana, Stephanodiscus parvus, Suririella striatula, Fragilaria fasciculata and Navicula veneta can be indicators of brackish conditions (Table II). These diatoms decrease slightly up core in Horseshoe Lake (Fig. 3B) and remain more or less constant in Lake Louise (Fig. 5A) and Salt Lake (Fig. 4B). The slight shifts in brackish diatoms (50 to 68\%) in Lake Louise (Fig. 5A) are likely related to lake level fluctuations and/or other environmental variables (e.g., turbidity, light penetration, nutrient supply, etc.). In Salt Lake, brackish diatoms are elevated (56-70\%), except during the interval where diatoms are altogether absent (Fig. 4B). A relic lake shore within Salt Lake is visible on airphotos (Fig. 2C) and this suggests that lake levels have fluctuated significantly with regional shifts in precipitation and evaporation. The barren zones (84 to $86 \mathrm{~cm}$ and 92 to $104 \mathrm{~cm}$ ) may indicate a decrease in diatom bloom caused by reduced light penetration in the water column from increased suspended sediment in the lake. The presence of both thecamoebians and Trochammina macrescens cf. polystoma, albeit in reduced abundances, in this depth range suggests the lake did not dry up entirely during this interval. The presence of Trochammina macrescens cf. polystoma, a brackish-water taxon (Scott et al., 2001), suggests the formation of a hypersaline brine. Trochammina macrescens cf. polystoma, Centropyxis aculeata and Arcella vulgaris all increase up core (Fig. 4C) and may indicate increased lake salinity through time.

\section{SEDIMENTATION RATES}

Sedimentation rates, based on the above pollen chronologies, are estimated for Horseshoe and Salt lakes where the base of Zone II is well defined. Key age markers are set at 2000 (top of the core), 1888 (Salsola marker), 1812 (Zone I to Zone II transition) and the basal core age, if known (Table I). Horseshoe Lake has an average sedimentation rate of 2.7 millimetres per year for the last 112 years (1888-2000). The average sedimentation rate is lower ( 1.1 millimetres per year) between 1812 and 1888 (Table III). While some compaction has undoubtedly occurred in the lower part of the core, this alone cannot account for the more than twofold increase in sedimentation rate. We propose the sharp increase in post-1888 sedimentation reflects landscape disturbance from settlement and the commencement of agricultural practices (i.e., the presence of plowed fields, especially during flood periods), as has been seen in other parts of the Northern Great Plains (De Boer, 1994; Shapley et al., 2005) and the Great Lakes region (Ekdahl et al., 2004; Finkelstein et al., 2005; McFadden et al., 2005; Wolin and Stoermer, 2005). The sedimentation rate, for the period $1160 \pm 50$ to 1812 at Horseshoe Lake, is estimated to be 0.7 millimetres per year. Salt Lake's sedimentation rates are significantly higher (6.3 millimetres per year between 1888-2000 and 3.4 millimetres per year between

\section{TABLE III}

Average sedimentation rates of lakes prior to landscape disturbance, after arrival of European settlers, and after the onset of modern agricultural practices

\begin{tabular}{lccc}
\hline Core location & Period & $\begin{array}{c}\text { Depth } \\
\text { range }(\mathrm{cm})\end{array}$ & $\begin{array}{c}\text { Sedimentation } \\
\text { rate }(\mathrm{mm} / \mathrm{a})\end{array}$ \\
\hline Horseshoe Lake & $1888-2000$ & $0-30$ & 2.7 \\
& $1812-1888$ & $30-40$ & 1.3 \\
& $1160-1812$ & $40-84$ & 0.7 \\
Lake Louise & $1812-2000$ & $0-35$ & 1.9 \\
Salt Lake & $1888-2000$ & $0-70$ & 6.3 \\
& $1812-1888$ & $70-100$ & 3.9 \\
& ????-1812 & $100-123$ & $\mathrm{~N} / \mathrm{A}$ \\
\hline
\end{tabular}


1812-1888) despite a greater distance from the river. We suggest that higher sedimentation is caused by Salt Lake receiving larger amounts of sediment from local sources, in addition to sediment input during Red River floods.

Other studies along the Red River in southern Manitoba have also reported an increase in post-settlement sedimentation rates. Brooks and Grenier (2001) estimated a sedimentation rate of 2.5 millimetres per year for the period 1880-1999, which is comparable to the rate observed at Horseshoe Lake. In their study, the pre-settlement sedimentation rate was 0.24 millimetres per year, even lower than that observed at Horseshoe Lake. Brooks (2002), based on anthropogenic debris in the river bank, also notes an order of magnitude increase in recent sedimentation along the banks of the Red River (from 1.6 millimetres per year to 14.3 millimetres per year). In contrast, his average rates of sedimentation over the past one to four millennium are on the order of 2-4 millimetres per year.

Cretaceous foraminifera do not outcrop in the vicinity of the floodplain lakes yet they increase from Zone I to Zone II in both Horseshoe and Salt lakes. The provenance of these microfossils in Horseshoe Lake is believed to be from outcrops of Cretaceous marine shales along the Sheyenne River, a tributary in the upper reaches of the Red River watershed in North Dakota (Medioli and Brooks, 2003) where Cretaceous bedrock is present. The increased abundance of the older reworked microfossils in the younger sediments is, therefore, indicative of increased sediment supply from the upper reaches of the Red River basin during the last 200 years. Whether this is also applicable to Salt Lake is not clear as it is situated at a much greater distance from the Red River.

\section{CONCLUSIONS}

Two distinct pre- and post-settlement zones are identified in cores from Horseshoe Lake and Salt Lake, whereas only a post-settlement record is observed in the Lake Louise core. The pre-settlement landscape (prior to $\sim 1812$ ) consisted of tall grass prairie and riparian forests whereas the post-settlement landscape presently comprises cultivated fields and riparian forest regrowth. Changes to the landscape occurred rapidly in the mid- to late- $19^{\text {th }}$ century, due to the introduction of cereal grass cultivation and associated weed taxa, and riparian deforestation associated with the influx of European settlers. By the beginning of the $20^{\text {th }}$ century, riparian forest regrowth had begun and by the end of the century the forests had recovered to pre-settlement proportions Simultaneously, as a result of the changeover from tall grass prairie to tilled land, the concentration of herbaceous pollen began a slow, steady decline to present day levels. Diatom and thecamoebian assemblages show a clear shift from more oligotrophic to highly eutrophic limnological conditions, beginning in the $19^{\text {th }}$ century and continuing throughout the $20^{\text {th }}$ century, reflecting the changing landscape and the introduction of agricultural fertilizers. Lakes that were probably once clear are now rich in macrophyte plant growth. Increased lake water salinity at Salt Lake and decreased salinity at Horseshoe Lake coincide with the period of rapid settlement (post-1880) and agricultural expansion. The salinity of Lake Louise has remained more or less constant throughout Zone II. Sedimentation rates increased twofold during the post-settlement period due to the transition from tall grass prairie to agricultural fields and have contributed to poorer lake water quality and sedimentwater interface anoxia.

The overall paleoenvironmental changes observed in the lake basins are consistent with those observed in other regions of the Northern Great Plains during this time period (Brooks and Grenier, 2001; Burbidge and Schröder-Adams, 1998; Jacobson and Engstrom, 1989; Shapley et al., 2005; Torigai et al., 2000). Widespread deforestation and destruction of the natural prairie ecosystem during the last two centuries has resulted in increased sedimentation in prairie lake basins, as well as increased eutrophication through time. The riparian forests have regrown but the tall grass prairie has been replaced by croplands. As a result of these changes, lacustrine sedimentation has increased twofold and lake waters have undergone eutrophication. The lake trophic levels are unlikely to return to natural levels in the foreseeable future as nutrients continue to be added to the basins through the use of crop fertilizers. The results from these lakes add to the growing body of evidence that documents widespread changes in nutrient levels and sedimentation rates in agricultural regions of the northeastern Great Plains.

\section{ACKNOWLEDGEMENTS}

Project financial support was provided by the CanadaManitoba Agreement on Red River Valley Flood Protection. Property owners are thanked for core site access. D. Berk and E. Nielsen (Manitoba Geological Survey) provided logistical support, C. Prévost assisted in lake coring, and C. Van Hoof aided in core subsampling. The United States Geological Survey kindly granted permission to sample Salt Lake, North Dakota. This paper was greatly improved by the comments from Drs. R.J. Mott and G.R. Brooks, as well as two anonymous reviewers. This paper represents Geological Survey of Canada contribution number 2005444.

\section{REFERENCES}

Appleby, G.G. and Oldfield, F., 1978. The calculation of lead-210 dates assuming a constant rate of supply of unsupported ${ }^{210} \mathrm{~Pb}$ to the sediment. Catena, 5: $1-8$.

Anderson, R.Y., Bradbury, J.P., Dean, W.E. and Stuiver, M., 1993. Chronology of Elk Lake sediments: coring, sampling, and time-series construction, p. 37-44. In J.P. Bradbury and W.E. Dean, ed., Elk Lake, Minnesota: Evidence of Rapid Climate Change in the North-Central United States. Geological Society of America, Special Paper 276, 336 p.

Anderson, T.W., 2003. Palynological analysis of Lake Winnipeg 99-900 cores 3, 4 and 8, p. 359-365. In S.L. Simpson, L.H. Thorleifson, C.F.M. Lewis, and J.W. King, ed., 1999 Lake Winnipeg Project: Cruise Report and Scientific Results. Geological Survey of Canada, Ottawa, Open File 4196, 430 p.

Batterbee, R.W., 1986. Diatom Analysis, p. 527-570. In B.E. Berglund, ed., Handbook of Holocene Palaeoecology and Palaeohydrology. John Wiley and Sons, Toronto, $869 \mathrm{p}$.

Beatley, J.C., 1973. Russian-Thistle (Salsola) species in the western United States. Journal of Range Management, 26: 225-226.

Betcher, R.N., Grove, G. and Pupp, C., 1995. Groundwater in Manitoba: hydrogeology, quality concerns, management. National Hydrology Research Institute, Contribution CS93017, 47 p. 
Bradbury, J.P. and Dean, W.E., 1993. Elk Lake, Minnesota: Evidence of Rapid Climate Change in the North-Central United States. Geological Society of America, Boulder, Special Paper 276, 336 p.

Bradbury, J.P. and Dietrich-Rurup, K.V., 1993. Holocene diatom paleolimnology of Elk Lake Minnesota, p. 215-238. In J.P. Bradbury and W.E. Dean, ed., Elk Lake, Minnesota: Evidence of Rapid Climate Change in the NorthCentral United States. Geological Society of America, Boulder, Special Paper 276, $336 \mathrm{p}$

Brugam, R.B., 1993. Surface sample analogues of Elk Lake fossil diatom assemblages, p. 189-214. In J.P. Bradbury and W.E. Dean, ed., Elk Lake, Minnesota: Evidence of Rapid Climate change in the North-Central United States. Geological Society of America, Boulder, Special Paper 276, 336 p.

Brugam, R.B., Bala, I., Martin, J., Vermillion, B. and Retzlaff, W., 2003. The sedimentary record of environmental contamination in Horseshoe Lake, Madison County, Illinois. Transactions of the Illinois State Academy of Science, 3: 205-217.

Brooks, G.R., 2002. Floodplain chronology and vertical sedimentation rates along the Red River, southern Manitoba. Géographie physique et Quaternaire, 56: 171-180.

Brooks, G.R., 2003a. Alluvial deposits of a mud-dominated stream: the Red River, Manitoba, Canada. Sedimentology, 50: 441-458.

Brooks, G.R., 2003b. Holocene lateral channel migration and incision of the Red River, Manitoba, Canada. Geomorphology, 54: 197-215.

Brooks, G.R., in press. Overbank deposition along the concave side of the Red River meanders, Manitoba, and its geomorphic significance. Earth Surface Processes and Landforms.

Brooks, G.R. and Grenier, A., 2001. Late Holocene pollen stratigraphy of Lake Louise, Manitoba. Geological Survey of Canada, Ottawa, Current Research 2001-B1, 7 p.

Brooks, G.R. and Medioli, B.E., 2003. Deposits and cutoff ages of Horseshoe and Marion oxbow lakes, Red River, Manitoba. Géographie physique et Quaternaire, 57: 151-158.

Brooks, G.R. and Nielsen, E., 2000. Red River, Red River Valley, Manitoba. The Canadian Geographer, 44: 304-309.

Brooks, G.R., Thorleifson, L.H. and Lewis, C.F.M., 2004. Influence of loss of gradient from postglacial uplift on Red River flood hazard, Manitoba, Canada. The Holocene, 15: 347-352.

Burbidge, S.M. and Schröder-Adams, C.J., 1998. Thecamoebians in Lake Winnipeg: a tool for Holocene paleolimnology. Journal of Paleolimnology, 19: 309-328.

Carlson, W. and Masterson, I., 1950. History of Emerson; reprinted (1975) as Recalling the past; exerts from the original History of Emerson, p. 37-62. In J. McClelland and D. Lewis, ed., Emerson 1875-1975-A Centennial History. Town of Emerson, Emerson, $109 \mathrm{p}$.

Dalton, C., Birks, H.J.B., Brooks, S.J., Cameron, N.G., Evershed, R.P., Peglar, S.M., Scott, J.A. and Thompson, R., 2005. A multi-proxy study of lake-development in response to catchment changes during the Holocene at Lochnager, north-east Scotland. Palaeogeography, Palaeoclimatology and Palaeoecology, 221: 175-201.

Dawson, G.M., 1875. Report on the geology and resources of the region in the vicinity of the forty-ninth parallel, from the Lake of the Woods to the Rocky Mountains with lists of plants and animals collected, and notes on the fossils. British North American Boundary Commission, 387 p.

De Boer, D.H., 1994. Lake sediments as indicators of recent erosional events in an agricultural basin on the Canadian prairies, p. 125-132. In L.J. Olive, R.J. Loughran and J.A. Kesby, ed., Variability in Stream Erosion and Sediment Transport. Proceedings of the Canberra Symposium, International Association of Hydrological Sciences, IAHS Publication No. 224, 498 p.

Dewey, L.H., 1895. Distribution of Russian Thistle in North America. Botanical Gazette, 20: 501.

Ekdahl, E.J., Teranes, J.L., Guilderson, T.P., Turton, C.L., McAndrews, J.H., Wittkop, C.A. and Stoermer, E.F., 2004. Prehistorical record of cultural eutrophication from Crawford Lake, Canada. Geology, 32: 745-748.

Faegri, K. and Iversen, J., 1964. Textbook of modern pollen analysis. Scandinavian University Books, Copenhagen, 237 p.
Finkelstein, S.A., Peros, M.C. and Davis, A.M., 2005. Late Holocene paleoenvironmental change in a Great Lakes coastal wetland: integrating pollen and diatom datasets. Journal of Paleolimnology, 33: 1-12.

Forrest, F., Reavie, E.D. and Smol, J.P., 2002. Comparing limnological changes associated with $19^{\text {th }}$ century canal construction and other catchment disturbances in four lakes within the Rideau Canal system, Ontario, Canada. Journal of Limnology, 61: 183-197.

Germain, H., 1981. Flore des Diatomées. Diatomophycées: eaux douces et saumâutres du Massif armoricain et des contrées voisines d'Europe occidentale. Société nouvelle des éditions Boubée, Paris, $444 \mathrm{p}$.

Grimm, E.C., 1991. TILIA and TILIAGRAPH. Illinois State Museum, Springfield.

Hanuta, I., 2001. A reconstruction of wetland information in pre-settlement southern Manitoba using a geographic information system. Canadian Water Resources Journal, 26: 183-194.

Henderson, P.J. and Last, W.M., 1999. Holocene sedimentation in Lake Winnipeg, Manitoba, Canada: implications of compositional and textural variation. Journal of Paleolimnology, 19: 265-284.

Jacobson, H A. and Engstrom, D.R., 1989. Resolving the chronology of recent lake sediments: an example from Devils Lake, North Dakota. Journal of Paleolimnology, 2: 81-97.

Kliza, D.A. and Schröder-Adams, C.J., 1999. Holocene thecamoebians in freshwater lakes on Bylot Island, Northwest Territories, Canada. Journal of Foraminiferal Research, 29: 26-36.

Krammer, K. and Lange-Bertalot, H., 1986-1991. Bacillariophyceae, In H. Ettl, J. Gerloff, H. Heynig, and D. Mollenhaur, ed., Susswasserflora von Mitteleuropa, band 2/1 to 2/4. Gustav Fisher Verlag, Stuttgart, (band 2/1) 876 p., (band 2/2) 596 p., (band 2/3) 576 p., (band 2/4) 437 p.

Last, W.M., 1982. Chemical and clastic sedimentation in Lake Manitoba, Canada. International Congress on Sedimentology, 11: 128.

Last, W.M., 1983. Modern sedimentology and hydrology of Lake Manitoba, Canada. Environmental Geology and Water Sciences, 5: 177-190.

Last, W.M., 1999. Geolimnology of the Great Plains in western Canada, p. 23-56. In D.S. Lemmen and R.E. Vance, ed., Holocene Climate and Environmental Change in the Palliser Triangle: a Geoscientific Context for Evaluating the Impacts of Climate Change on the Southern Canadian Prairies. Geological Survey of Canada, Ottawa, Bulletin 534, 229 p.

Last, W.M., Teller, J.T. and Forester, R.M., 1994. Paleohydrology and paleochemistry of Lake Manitoba, Canada: the isotope and ostracode records. Journal of Paleolimnology, 12: 269-282.

Lemmen, D.S. and Vance, R.E., 1999. Holocene Climate and Environmental Change in the Palliser Triangle: a Geoscientific Context for Evaluating the Impacts of Climate Change on the Southern Canadian Prairies. Geological Survey of Canada, Ottawa, Bulletin 534, p. 295.

Lewis, C.F.M., Anderson, T.W., Forbes, D.L., Nielsen, E. and Thorleifson, L.H., 2001. Investigation of Lake Winnipeg sediments: a record of the last millennium, p. 33-63. In S. St. George, T.W. Anderson, D. Forbes, C.F.M. Lewis, E. Nielsen, and L.H. Thorleifson, ed., Climatic Extremes in Southern Manitoba During the Past Millennium. Final Report to the Canadian Climate Change Action Fund, Environment Canada, $430 \mathrm{p}$.

Macoun, J., 1882., Manitoba and the Great North-West. World Publishing Company, Guelph, 687 p.

McClelland, J., 1975. Emerson during the 1880s: the town, the people and the railroad, p. 5-36. In J. McClelland and D. Lewis, ed., Emerson 1875-1975-A Centennial History. Town of Emerson, Emerson, 109 p.

McFadden, M.A., Patterson, W.P., Mullins, H.T. and Anderson, W.T., 2005. Multiproxy approach to long- and short-term Holocene climate change: evidence from eastern Lake Ontario. Journal of Paleolimnology, 22: 371-391.

Medioli, B.E., 2001. Geochemical, grain size, mineralogical and chronological data from three shallow cores in the Red River Valley (Horseshoe Lake, Lake Louise, Manitoba and Salt Lake, North Dakota). Geological Survey of Canada, Ottawa, Open File 4025, 80 p.

Medioli, B.E., 2003. Search for a paleoflood record using physical and geochemical properties of cores from shallow lakes, Red River valley, Manitoba and North Dakota. Geological Survey of Canada, Ottawa, Current Research 2003-B1, 11 p. 
Medioli, B.E. and Brooks, G.R., 2003. Diatom and thecamoebian signatures of the Red River (Manitoba and North Dakota) floods: data collected from the 1997 and 1999 spring freshets. Journal of Paleolimnology, 29: 353-386.

Medioli, F.S. and Scott, D.B., 1983. Holocene Arcellacea (Thecamoebians) from Eastern Canada. Cushman Foundation for Foraminiferal Research, Special Publication 21, $63 \mathrm{p}$.

Medioli, F.S. and Scott, D.B., 1988. Lacustrine thecamoebians (mainly Arcellaceans) as potential tools for palaeolimnological interpretations. Palaeogeography, Palaeoclimatology and Palaeoecology, 62: 361-386.

Nielsen, E., 1999. Lake Winnipeg coastal submergence over the last three centuries. Journal of Paleolimnology, 19: 335-342.

Nuhfer, E.B., Anderson, R.Y., Bradbury, J.P. and Dean, W.E., 1999. Modern sedimentation in Elk Lake, Clearwater County, Minnesota, p. 75-96. In J.P. Bradbury and W.E. Dean, ed., Elk Lake, Minnesota: Evidence of Rapid Climate Change in the North-Central United States. Geological Society of America, Boulder, Special Paper 276, 336 p.

Patrick, R. and Reimer, C.W., 1966. The diatoms of the United States exclusive of Alaska and Hawaii. Monographs of the Academy of Natural Sciences of Philadelphia Number 13, 1: 1-688.

Patrick, R. and Reimer, C.W., 1975. The diatoms of the United States. Monographs of the Academy of Natural Sciences of Philadelphia Number 13, 2: 1-213.

Ross, A., 1856. The Red River Settlement: its Rise, Progress and Present State. Smith, Elder and Company, London, $416 \mathrm{p}$.

Schrader, H.J. and Gersonde, R., 1978. Diatoms and silicoflagellates. Utrecht Micropaleontological Bulletin, 17: 129-176.

Scott, D.B., Medioli, F.S. and Schafer, C.S., 2001. Monitoring Coastal Environments using Foraminifera and Thecamoebian Indicators. Cambridge University Press, New York, 208 p.

Shapley, M.D., Johnson, W.C., Engstrom, D.R. and Osterkamp, W.R., 2005. Late-Holocene flooding and drought in the Northern Great Plains, U.S.A., reconstructed from tree rings, lake sediments and ancient shorelines. The Holocene, 15: 28-41.

St. George, S. and Nielsen, E., 2001. A 591-yr Record of Annual Precipitation in Winnipeg Derived from Tree Rings. In S. St. George, T.W. Anderson, D. Forbes, C.F.M. Lewis, E. Nielsen and L.H. Thorleifson, ed., Climatic Extremes in Southern Manitoba During the Past Millennium. Climate Change Action Fund Final Report, $16 \mathrm{p}$.

St. George, S. and Nielsen, E., 2002. Hydroclimatic change in southern Manitoba since A.D. 1409 inferred from tree rings. Quaternary Research, 58: 103-111.

St. George, S. and Nielsen, E., 2003. Palaeoflood records for the Red River, Manitoba, Canada, derived from anatomical tree-ring signatures. The Holocene, 13: 547-555.
Stuiver, M., Reimer, P.J., Bard, E., Beck, J.W., Burr, G.S., Hughen, K.A., Kromer, B., McCormac, G., van der Plicht, J. and Spurk, M., 1998. INTCAL98 radiocarbon age calibration, 24,000 cal BP. Radiocarbon, 40: 1041-1083.

Tackman, G.E., Currey, D.R. and James, T.S., 1999. Paleoshoreline evidence for postglacial tilting in southern Manitoba. Journal of Paleolimnology, 19: 343-363.

Talma, A.S. and Vogel, J.C., 1993. A simplified approach to calibrating ${ }^{14} \mathrm{C}$ dates. Radiocarbon, 35: 317-322.

Teller, J.T. and Last, W.M., 1981. Late Quaternary history of Lake Manitoba, Canada. Quaternary Research, 16: 97-114.

Teller, J.T. and Last, W.M., 1983. Holocene climate and hydrology of Lake Manitoba, p. 333-353. In J.T. Teller and L. Clayton, ed., Glacial Lake Agassiz. Geological Association of Canada, St. Jonh's, Special Paper 26, 451 p.

Todd, B.J., Lewis, C.F.M., Thorleifson, L.H., Nielsen, N. and Last, W.M., 1999a. Paleolimnology of Lake Winnipeg: introduction and overview of special issue. Journal of Paleolimnology, 19: 215-244.

Todd, B.J., Lewis, C.F.M., Nielsen, N., Thorleifson, L.H., Bezys, R.K. and Weber, W., 1999b. Lake Winnipeg: geological setting and sediment seismostratigraphy. Journal of Paleolimnology, 19: 215-244.

Torigai, K., Schröder-Adams, C.J. and Burbidge, S.M., 2000. A variable lacustrine environment in Lake Winnipeg, Manitoba: evidence from modern thecamoebian distribution. Journal of Paleolimnology, 23: 305-318.

Travel Manitoba, 2005. Citing online source: Manitoba Population (available online at http://www.travelmanitoba.com, last accessed on June 6, 2006).

Warkentin, J. and Ruggles, R.I., 1970. Historical Atlas of Manitoba: A Selection of Facsimile Maps, Plans and Sketches from 1612 to 1969. Manitoba Historical Society, Winnipeg, $585 \mathrm{p}$.

Wetzel, R.G., 2001. Limnology: Lake and River Ecosystems (3 ${ }^{\text {rd }}$ Edition) Academic Press, New York, 1006 p.

Whitlock, C., Bartlein, P.J. and Watts, W.A., 1999. Vegetational history of Elk Lake, p. 251-276. In J.P. Bradbury and W.E. Dean, ed., Elk Lake, Minnesota: Evidence of Rapid Climate Change in the North-Central United States. Geological Society of America, Boulder, Special Paper 276, 336 p.

Wilson, S.E., Cummings, B.F. and Smol, J.P., 1996. Assessing the reliability of salinity inference models from diatom assemblages: an examination of a 219-lake set from western North America. Canadian Journal of Fisheries and Aquatics, 53: 1580-1594.

Wolin, J.A. and Stoermer, E.F., 2005. Response of a Lake Michigan coastal lake to anthropogenic catchment disturbance. Journal of Paleolimnology, 33: 73-94. 